Carla HUERTA

Resumen:

La filosofia del derecho es una reflexión general y sistemática sobre las cuestiones fundamentales del derecho. El hecho de que términos como "filosofia del derecho", "teoría del derecho" y "jurisprudencia" no tengan significados delimitados e indisputables, a pesar de los esfuerzos de los juristas contemporáneos, es una de las razones que junto con las transformaciones del derecho en virtud de la globalización y las teorías sobre derechos humanos han dado lugar a diversas disputas sobre la función y validez de la filosofia del derecho. En este artículo se pretende establecer una base común para la discusión en torno a estos problemas mediante la revisión de algunas de las diferencias que las dos principales tradiciones occidentales para después describir la precepción general y evolución de la filosofia del derecho.

Palabras clave:

Análisis conceptual, filosofia analítica del derecho, metodología de la filosofía jurídica, filosofia del derecho continental.

\title{
Abstract:
}

Legal philosophy is a general and systematic reflection about fundamental questions regarding law. The fact that despite the efforts of contemporary jurists terms like 'legal philosophy', 'legal theory' and 'jurisprudence' do not have established meanings is one of the reasons behind the dispute regarding the function and validity of legal philosophy; a second issue worth 


\section{CARLA HUERTA}

considering is the transformations of law due to diverse influences such as globalization or theories on human rights. This article intends to establish common ground for the discussion surrounding this issue by revisiting some of the differences between the two main western traditions, the article then proceeds to describe the general perception and evolution of jurisprudence.

Keywords:

Conceptual Analysis, Analytical Jurisprudence, Methodology of Jurisprudence, Continental Jurisprudence. 
Summary: I. Legal Philosophy. II. Jurisprudence. III. Analytical Jurisprudence. Final Remarks.

Contemporary discussion on legal philosophy has dealt mainly with the following topics: the delimitation of legal theory within this discipline, the difference between legal dogmatic and legal science, and the distinction that arises within legal theory as a consequence of the choice between an analytical method and a synthetic one. Another topic discussed lately is whether the influence of globalization in general jurisprudence could reflect the need of a less parochial jurisprudence, especially in view of the pretense that it be considered universal and not only in the sense of general abstraction. The debate is never-ending and the fact that the terms 'legal philosophy', 'legal theory' and 'jurisprudence' do not have established undisputed meanings contributes to this dispute.

In the last decades, much criticism surrounding the philosophical method of conceptual analysis in legal theory has attempted to undermine it. I do not intend to devote this paper to responding to the objections made (which have already been largely discussed), but rather to revisit certain aspects of analytical jurisprudence that could explain why some scholars embrace it and others reject it. ${ }^{1}$ To do this adequately and honoring the methods of analytical jurisprudence, I would like to address this issue by making some clarifications as to what is understood as jurisprudence in the Continental and the British traditions.

\section{LEGAL PHILOSOPHY}

What is law is the question to be dealt with, but the dispute does not reside in the object of the discipline. Prob-

1 Some of the debates seem to have verged into an obsession, turning the analysis of law into a secondary activity with respect to these questions. 
lems arise regarding the methodology, the scope of the analysis and even in the possibility of knowing and explaining law. Discussing such issues makes one wonder if legal philosophy is an important activity. Whether this is a relevant question or not seems to be part of the problem and the answer to these questions is related to the question of the importance of philosophy, a matter that will not be dealt with in this paper. ${ }^{2}$

Philosophical reflection on law is as old as law itself, but the term "legal philosophy" is used only after Hegel publishes the Principles of Legal Philosophy (1821). Lato sensu, it refers to a systematic reflection on the meaning of law, its relation to justice, the science of law, the structure of the legal system or legal reasoning. The expression 'general theory of law' only appears in the late $19^{\text {th }}$ century as a consequence of the influence of empiricism and positivism, and as a reaction to legal philosophy to discard the metaphysical considerations that affected the scientific nature of the study on law. ${ }^{3}$

Legal philosophy is a branch of philosophy, not stemming from legal science and different from legal dogmatic; ${ }^{4}$ it is a special kind of general philosophy because it answers fundamental legal questions and problems that are reflected upon and discussed philosophically. ${ }^{5}$ Philosophy is a gen-

2 For Pieper, philosophy is meaningful and necessary; philosophy is something all human beings do; it is the road to knowledge, to a better understanding. In this work, he defends his understanding of philosophy and the philosophical impulse against common objections and deformations. Pieper, Josef, In Defense of Philosophy, Ignatius Press, 1992.

3 Troper, Michel, La filosofía del Derecho, transl. Ma. Teresa GarcíaBerro, Madrid, Tecnos, 2008, pp. 30-31.

4 It is called dogmatic with regard of the Kantian method of pure reason because jurists work with presuppositions that they accept unproven as true.

5 Kaufmann, "Problemgeschichte der Rechtsphilosophie", in Kaufmann, Hassemer, Neumann (eds.), Einführung in Rechtsphilosophie und Rechtstheorie der Gegenwart, 7th ed., Heidelberg, C.F. Müller Verlag, 2004, p. 1. 
eral and systematic reflection about fundamental questions. It is a conceptual activity that has a critical dimension, normative in the sense that it distinguishes what is right, best or correct; an analytic dimension to identify and make explicit fundamental structures, concepts and principles; and a synthetic dimension that attempts to unite it all into a coherent whole. ${ }^{6}$

According to Bertrand Russell, "philosophy, like all other studies, aims primarily at knowledge. The knowledge it aims at is the kind of knowledge which gives unity and system to the body of the sciences, and the kind which results from a critical examination of the grounds of our convictions, prejudices and beliefs". ${ }^{7}$ Considering the function of legal philosophy, Pound writes that "philosophies of law have been attempts to give a rational account of the law of the time and place, or attempts to formulate a general theory of the legal order to meet the needs of some given period of legal development, or attempts to state the results of the two former attempts universally and to make them all-sufficient for law everywhere and for all time". 8

Legal philosophy, as part of philosophy, is therefore a general and systematic reflection about fundamental questions regarding law; its reasoning about law and philosophy is the method to describe social phenomena. It produces a description of law that is characterized by being highly abstract and generalized. Accounting for the nature of law has therefore multiple dimensions: a normative one, an analytic one and a holistic one. The systematic and critical nature of legal philosophy requires a rational system for its analysis that comprises the pre-understanding of law and philoso-

6 Alexy, Robert, "The Nature of Legal Philosophy", in Associations, Journal for Legal and Social Theory, edited by Aulis Aarnio, Berlin, Duncker \& Humblot, vol. 7, num. 1, 2003, pp. 64-65.

7 Russell, Bertrand, The Problems Of Philosophy, Opus, Oxford, Oxford University Press, (1912) 1998, p. 90.

8 Pound Roscoe, An Introduction to the Philosophy of Law, New haven and London, Yale University Press, (1922) 1982, pp. 3-4. 
phy, but according to Alexy, the best option is not an abstract theory of legal philosophy, but the systematic analysis of the arguments put forth in the discussion on the nature of law. ${ }^{9}$

Legal philosophy deals with three main problems: what law is, which addresses the ontological question which considers concepts of norms and the legal system; problems of validity (authoritative issuance) and efficacy (social dimension); and legitimacy concerning the relationship between law and morality (the ideal or critical dimension of law). These problems can be analyzed on the basis of three questions: an ontological one (what law is), an ethical one (what ought to be done) and an epistemological question (what we can know). Meanwhile, all the answers should be connected by a coherent theory that explains law. ${ }^{10}$

Questions about the nature of law are questions about its necessary properties (such as coercion or sanction) and the concept of necessity is at the heart of philosophy. The idea of necessary features is central to the explanation of law as a concept and does not make the description of the relevant properties of a particular legal system according to the method of analytical jurisprudence impossible or futile. The pursuit of knowledge of necessary features of law does not rule out any kind of empirical investigation since the philosophical method does not exclude empirical knowledge; ${ }^{11}$ legal theory in fact analyses norm sentences, which are facts given by the legislator. And according to Guibourg, in legal theory, for example, analytical jurisprudence requires that the moral value of law be proven to provide empirical data of the constitutive meaning of a legal concept while considering the logical structure of the legal discourse and to strive for a coherent theoretical model that explains so-

9 Alexy, op. cit., note 6, p. 66.

10 Ibidem, p. 67.

11 Kaufmann explains that legal philosophy is directed at experience and experiment. The experiment is its presence in history while opinions on historical problems are posed in a real discourse, op. cit., note 5, p. 27. 
cial phenomena while grounding comprehensible arguments. ${ }^{12}$

The purpose of legal philosophy is to explain what law is, to aid in its understanding. As Alexy has clearly stated, legal philosophy, understood as reasoning on the nature of law, is intended to answer the fundamental questions about law. In this sense, it also includes the problems of philosophy in general besides the special problems concerning the specific character of law. In its analysis, it is relevant to consider the special relation between legal philosophy and other provinces of practical philosophy; i.e. moral and political philosophy, and in Alexy's opinion, this should not be a matter of choice because legal philosophy comprehends all of these perspectives. ${ }^{13}$

Kaufmann believes the task of all legal philosophy is to distinguish - directly or indirectly - what is legal from what is just (Recht vom Unrecht zu unterscheiden); in other words, to answer the question on justice as criteria to measure positive law and in that sense answer the question on the validity of law. To treat them as separate questions has led to consider legal philosophy on one hand and methodology of law on the other. ${ }^{14}$ Troper says that as a discipline, it comprises a legal ontology that searches for the essence of law and of some concepts, a legal epistemology conceived as the examination of the possibilities to achieve the knowledge of essences, a legal teleology that tries to determine the objective of law and a legal logic that pursues the analysis of legal argumentation. ${ }^{15}$

Legal philosophers have different views as to what counts as law, what belongs to the object to be explained, but that

12 Guibourg, Ricardo, "El derecho ante el enfoque analitico", Instituto de Filosofía del Derecho, num. 10, Academia Nacional de Derecho y Ciencias Sociales de Córdoba, Córdoba, Argentina, 2007, p. 297.

13 Alexy calls this the comprehensive ideal of legal philosophy, Alexy, op. cit., note 6, pp. 67-68.

14 Kaufmann, op. cit., note 5, p. 26.

15 Troper, op. cit., note 3, pp. 32-33. 
some legal philosophers have a pre-theoretical understanding does not imply the impossibility of a general jurisprudence. On the contrary, this pre-understanding is a hermeneutical advantage.

Different conceptions on what law is are partly a consequence of embracing one of the two most important traditions in Western legal philosophy: legal positivism and natural law. Nevertheless, Alexy suggests that the choice between the comprehensive ideal and the restrictive maxim determines the character of legal philosophy qua philosophy more that the choice between positivism and non-positivism, since this later decision is made within the realm of legal philosophy. ${ }^{16}$ Analytical philosophy, for instance, is more a question of method than of being positivist or not, an epistemic attitude that relies on linguistic analysis, the facilitation of the development of empirical sciences and the rejection of metaphysical conceptions. ${ }^{17}$

Legal positivism establishes a specific connection between law and facts; the 'facticity thesis' claims the inseparability of law and fact. The reductive thesis is an aspect of the empirical-reductive legal positivism as opposed to the 'normativity thesis' that claims that law is explained independently of fact. Natural law, on the other hand, focuses on the (necessary) connection between law and morality, or the morality thesis, its antithesis being the 'separability thesis' represented by Hart's work. ${ }^{18}$

Legal philosophy is generally understood as a speculative and normative enterprise closely related to moral and political philosophy, but $20^{\text {th }}$ century jurists produced a profound transformation of jurisprudence. Especially after Hans Kelsen and H.L.A. Hart, legal philosophers consider the primary task of jurisprudence is descriptive, that is

16 Alexy, op. cit., note 6, p. 68.

17 Guibourg, op. cit., note 12, p. 296.

18 Paulson, Stanley, "Continental Normativism and Its British Counterpart: How Different are They?", Ratio Iuris, vol. 6, No. 3, December 1993, p. 40. 
"morally neutral and has no justificatory aims". ${ }^{19}$ Tradition in legal philosophy consists of the various answers offered in response to the question: What is law? Continental normativism offers a kind of legal theory conceptually distinct from both empirical-reductive legal positivism and natural law theory. Though for Paulson, Hart's theory does not challenge the thesis of exhaustiveness as Kelsen's Pure Theory of Law does. ${ }^{20}$

Legal philosophical considerations can also be found in other disciplines like juristic methodology, the general theory of State, legal logic inter alia. It investigates not only the traditional issues in abstracto such as the concepts of law, legal system, norm or validity for example, but also concrete problems as it noted in revisiting the meaning of "jurisprudence".

\section{JURISPRUDENCE}

As it is well known, the word "jurisprudence" has different meanings. Harris calls it a "ragbag" into which all kinds of speculations about law can be found. ${ }^{21}$ It is used in the sense of legal theory as well as to refer to judges' activity (as in 'case law' as used in France or Mexico, for instance). The term "jurisprudence" derives from the Latin "iuris prudentia" that is usually understood as the practical and theoretical activity of a jurist. Even though it is generally considered to refer to a judge's decisions, or making decisions with prudence, in the British tradition it is used to designate a general theory of law although there was once a time when it was used to refer to the analysis of legal concepts.

19 That is how Hart explains the descriptive nature of his work. See Hart, H. L. A., The Concept of Law, Oxford, Oxford University Press, 1994, p. 240 .

20 Paulson, op. cit., note 18, p. 228.

21 Harris, J. W., Legal Philosphies, London, Butterworths, (1980) 1995, p. 1. 
Jurisprudence is a branch of philosophy, of practical philosophy to be more precise, but it can be distinguished from moral and political philosophy as well as from sociological analysis, as a scientific pursuit that can be addressed in general or as particular jurisprudence. It is often divided into areas such as analytical jurisprudence, historical jurisprudence, sociological jurisprudence and critical jurisprudence (or theories of justice). Paraphrasing Barberis, jurisprudence (s.s.) is the discipline invented by philosophers like Hobbes and Bentham, identified in general with the work of Austin and later developed by the American realists and especially by Hart's analytical jurisprudence. It is a strictly legal and theoretical enterprise of the cognitive analysis of fundamental legal concepts, especially on the legal norm. ${ }^{22}$

For Austin, general jurisprudence, a philosophy of positive law, is a science that explains the principles, notions and common distinctions in systems of law, as a speculative line of investigation on positive law and therefore, philosophical knowledge. ${ }^{23}$ General jurisprudence according to Harris "raises questions of all kinds about law, which may involve analysis of law and other legal concepts". Harris holds that an analysis is jurisprudential if a term is investigated to ascertain a meaning common to different legal systems and to several branches of the law. ${ }^{24}$ The object of jurisprudence is positive law, "an order by which human conduct is regulated in a specific way. The regulation is accomplished by provisions which set forth how men ought to behave. Such provisions are called norms, and either arises through custom, as do the norms of the common law, or are enacted by conscious acts of certain organs aiming to

22 Barberis, Mauro, Una storia della filosofía del diritto, Bologna, I1 Mulino, 2004, p. 89.

23 Chiassoni, Pierluigi, L'uttopia de la ragione analitica. Origini, ogetti e metodi della filosofia del diritto positivo, Torino, G. Giappichelli Editore, 2005, pp. 45-46.

24 Harris, op. cit., note 21, p. 87. 
create law, as a legislature acting in its law-making capacity". 25

Generally speaking, "jurisprudence" is the term used to designate legal theory in Britain, as well as in other common law countries. This first and obvious remark seems irrelevant; nevertheless, it is of great relevance to dissipate the doubts surrounding the discussion on the various possible answers to what law is since it points to a relevant ground for the differences encountered: the object of cognition. Common law is created by practice; there is therefore a connection between historical jurisprudence and the justification of law offered for common law reasoning. It is a discipline that is more grounded on legal practice.

In countries in the western hemisphere and the legal systems that have received their legal systems from the same sources, one can identify two main models: the civil law and the common law systems influenced by two different periods of Roman law: ius civile or written law originating in the Twelve Tables up to the completion of Justinian's codifications and compilations, and case law when iuris prudentia flourished, respectively. The origin of common law systems in feudal Britain is characterized by local forms of dispute resolution until the establishment of circuit courts that provided a "common law" that built up equity as distinct and supplementary system. ${ }^{26}$ In civil law countries, legal writers formulate general theories generally expressed in the form of systematic arguments and discussions about broad legal principles and positive law. And doctrine is indispensable to a systematic and analytical understanding of the legal system. Doctrinal writings in common law

25 Kelsen, Hans, "The Pure Theory of Law and Analytical Jurisprudence", Harvard Law Review, Vol. 55, No. 1 (Nov., 1941), p. 50.

26 Dainow, Joseph, "The Civil Law and the Common Law: Some Points of Comparison", The American Journal of Comparative Law. University of Michigan, Baltimore, vol. 15, number 3, 1966-1967, pp. 419-435. 
countries frequently make reference to decided cases in order to compile them and evaluate their relevance. ${ }^{27}$

Jurisprudence in the United Kingdom is characterized by the analytical tradition that focuses on the theoretical approach to law, which is exceptionally critical, ${ }^{28}$ and by its insularity. This particularity sometimes makes it necessary for it to be "translated" so as to provide a common ground for discussion for legal theorists from both traditions, Continental and Anglo-Saxon, to communicate considering the different attitudes as to what legal philosophy, jurisprudence and legal theory are. Notwithstanding, jurisprudence is a conceptual inquiry concerned with offering an account of the "nature of law" that is general in the sense that it is applicable to all legal systems, and is morally neutral, in the sense that it does not judge the morality of law. But jurisprudence as a reflective and critic activity is evaluative, which does not mean necessarily morally evaluative. Judgments are the way to evaluate the relevance or importance of the topic discussed. Both disagreements and agreements are part of legal discourse; weighing the arguments and counter-arguments is key to solving a dispute. Bertrand Russell considers "the value of philosophy is, in fact, to be sought largely in its very uncertainty".29

According to Harris, in modern English usage "jurisprudence" stands for "general speculation of all kinds about the law, "legal theory" is used to cover inquiries about the nature of law and "legal philosophy" refers to the branch of practical philosophy that investigates the value implications of describing something as legal. ${ }^{30}$ Continental legal philosophy, on the contrary, stresses the difference between these concepts. Jurisprudence is the theoretical part of a discipline and, according to Twinning, its mission is the dissem-

27 Ibidem, p. 428.

28 The term "critical" refers either to assess the merits of the subject matter or that which involves the application of critical legal theory.

29 Russell, op. cit., note 7, p. 91.

30 Harris, op. cit., note 21 , p. 5 . 
ination of knowledge and critical understanding of law. As an activity of theorizing, it involves posing, answering and arguing general questions relating to the subject-matters of law. ${ }^{31}$ The construction of concepts and explanatory theories is critically examined by jurists and this kind of scientific activity is the source of many disagreements.

Chiassoni states that jurisprudence distinguishes between the non-authoritative jurisprudence general or universal jurisprudence and local jurisprudence in the sense that the latter studies the specific normative content of specific legal norms in a specific country. General jurisprudence focuses on the concepts of a given legal system, law and norm, and its purpose is to criticize or modify the law. It is a search for the meaning of legal concepts. General theories consider the law at diverse levels and in diverse countries. Local jurisprudence emphasizes the importance of customs and traditions of particular cultures. This kind of description is similar to that of legal dogmatic and more related to legal history than to legal theory, though local jurisprudence explains the concepts common to any positive legal system. ${ }^{32}$ Austin's work has the characteristics of a general jurisprudence, a scientific discipline that has positive law as its object in a descriptive discourse. Particular jurisprudence, or national jurisprudence, is a discipline oriented at legal practice in order to know the law in force in a specific political community, often called also legal dogmatic, legal doctrine or legal science. ${ }^{33}$ Jurisprudence can also be called particular in terms of the analysis of specific

31 Twinning, William, "General Jurisprudence", in Law and Justice in a Global Society, Anales de la cátedra Francisco Suárez, IVR Granada, Spain, 2005, p. 610.

32 Chiassoni, Pierluigi, L'uttopia de la ragione analitica. Origini, ogetti e metodi della filosofia del diritto positivo, Torino, G. Giappichelli Editore, 2005, p. 15.

33 Ibidem, p. 40. 
legal concepts as opposed to general jurisprudence understood as speculation about law. ${ }^{34}$

According to Paulson, one of the reasons for the differences between continental and British jurisprudence is that Hans Kelsen developed normativism based on the theoretical work of Kant, as opposed to British normativism that derived from Hume's empiricism, which finds its contemporary expression in Hart's legal theory. ${ }^{35}$ Each author sought to attain answers through the analysis of positive law. Although the Pure Theory of Law stands independently of Austin's lectures on general jurisprudence, even Kelsen admits that important points of his work concur with Austin's doctrine. Kelsen states that they differ in that he carried out the method of analytical jurisprudence more consistently than Austin and his followers did. In Kelsen's opinion, "this is true especially as to the central concept of jurisprudence, the norm. Austin does not employ this concept, and pays no attention to the distinction between 'is' and 'ought' that is the basis of the concept of the norm". ${ }^{36}$

Guastini declares that "proponents of normativism understand legal science as a 'normative' science in two senses: it has norms as its subject-matter, and its statements are (necessarily) formulated in normative (that is, deontic) language". ${ }^{37} \mathrm{He}$ believes that normative theory of legal science represents an attempt to describe (and to rationalize) the actual practice and thinking of contemporary jurists. The interpretation of legal material lies in the description of norms. ${ }^{38}$

Kelsen writes that "jurisprudence sees the law as a system of general and individual norms. Facts are considered

34 Harris, op. cit., nota 21, p. 4.

35 Paulson, op. cit., note 18, p. 241.

36 Kelsen, op. cit., note 25, pp. 54-55.

37 Guastini, Ricardo, "Normativism or the Normative Theory of Legal Science", in Paulson and Litchewski (eds.), Normativity and Norms. Critical Perspectives on Kelsenian Theory, Oxford, Clarendon Press, 1998, p. 318.

38 Ibidem, p. 319. 
in this jurisprudence only to the extent that they form the content of legal norms. Only norms, provisions as to how individuals should behave, are objects of jurisprudence, never the actual behavior of individuals". ${ }^{39}$ And the jurist, as the theoretical exponent of the law, presents these norms in propositions that have a purely descriptive sense, statements which only describe the "ought" of the legal norm. In his opinion "jurisprudence is to present law as a system of valid norms, the propositions by which it describes its object must be 'ought' propositions, statements in which an 'ought,' not an 'is,' is expressed. But the propositions of jurisprudence are not themselves norms". 40

Kelsen's theory limits itself to the cognition of positive law, and excludes from this cognition the philosophy of justice, as well as the sociology of law. Its orientation is much the same as that of analytical jurisprudence, which found its classical Anglo-American presentation in the work of John Austin. ${ }^{41}$ The difference between Austin's analytical jurisprudence and The Pure Theory of Law is that although Austin does distinguish law from moral, he includes issues from moral and political philosophy in the process of determining the province of jurisprudence, and of course did not intend to establish the parameters of legal science. Kelsen sustains that "...the specific science of law, the discipline usually called jurisprudence, must be distinguished from the philosophy of justice, on the one hand, and from sociology, or cognition of social reality, on the other". ${ }^{42}$

Legal theory or positive legal philosophy in occidental legal culture is the systematic study of positive law; the theoretic method of analytical jurisprudence derives its concepts only from an analysis of positive law. Its purpose is to explain law to describe said object in order to understand it and analyze it as a social phenomenon. Even if it hard to

39 Kelsen, op. cit., note 25, p. 50.

40 Idem.

41 Ibidem, p. 54.

42 Ibidem, p. 44. 
draw a precise line between legal philosophy and legal theory, it is true that that the first is more content oriented and the second discipline, more formal oriented. Both share some characteristics, such as the fact that they are not concerned with valid law, as in force, nor with legal facts, but both make systematic transcendental considerations on law. ${ }^{43}$ These disciplines aim at explaining law in general; legal theory is a sort of philosophy of jurists and its object is analyzed by lawyers from a legal perspective.

The concept "legal theory" can be used to refer to two different activities: a general description of "law" or a description of a particular legal system (with specific characteristics). Law is a type of social institution. As a social phenomenon, every legal system differs according to the nature of the society within which it arises. There is therefore indeterminacy rooted in the object of local jurisprudence related to the inability to anticipate the patterns of human conduct and their results. A kind of jurisprudence more grounded on empirical facts of particular legal systems resembles legal sociology more than jurisprudence strict sensu. Local jurisprudence is more sociological or political, than legal. As a discipline, it leads to a cultural enterprise more than a scientific one because this kind of particular jurisprudence is linked to specific political and social considerations. It also stresses the dilemma of trying to theorize law as genuinely normative, yet its being grounded on social fact is acute in the context of particular jurisprudence.

Descriptive and general legal theory is often perceived as opposite to an evaluative and justificatory legal theory, especially if it involves a particular legal culture, but they are actually two different enterprises, each with its own ends and methods. In general, the term "descriptive" refers to a normatively neutral legal theory, but the use of the term "normative" in legal philosophy is used in different ways. Sometimes, it refers to its capacity to answer "ought"-ques-

43 Kaufmann, op. cit., note 5, p. 9. 
tions (how the law should be, on the underlying values, which law is just, etc.) in the sense that jurisprudence describes its object - law- in ought-propositions or considering the nature of its object. Questions regarding law, therefore, require a normative perspective.

Normative analysis has two dimensions. The first one deals with the desirable content of law, which itself allows two kinds of discourse related to the theoretical relation between law and moral or the political discourse, and the pragmatic aspects of the structure of the legal phenomenon that each jurist considers appropriate. ${ }^{44}$ Normative jurisprudence deals with the validity of the law. According to Kelsen, "in view of the specific sense of the propositions in which jurisprudence describes its object, it can be called a normative theory of the law. This is what is meant by a specifically 'juristic' view of the law. This sort of jurisprudence must be clearly distinguished from another which can be called sociological". ${ }^{45}$ Continental jurisprudence has attempted to differentiate sociological jurisprudence from normative jurisprudence since each deals with completely different problems. And Kelsen clearly states that "legal theory answers the question of what the law is, not what it ought to be. The latter question is one of politics, while the pure theory of law is science". ${ }^{46}$ For Kelsen, it is fundamental to avoid under all circumstances "the confounding —as frequent as it is misleading - of cognition directed toward a legal 'ought,' with cognition directed toward an actual 'is". ${ }^{47}$

The best and foremost example of legal theory is the The Pure Theory of Law, which in Kelsen's words "is a theory of positive law; a general theory of law, not a presentation or interpretation of a special legal order". 48 Kelsen presents a revised version of legal positivism also known as "norma-

44 Guibourg, op. cit., note 12, p. 299.

45 Kelsen, op. cit., note 25, p. 50.

46 Ibidem, p. 44.

47 Ibidem, p. 50.

48 Ibidem, p. 44. 
tivism" that "from a comparison of all the phenomena which go under the name of law, it seeks to discover the nature of law itself, to determine its structure and its typical forms, independent of the changing content which it exhibits at different times and among different peoples. In this manner it derives the fundamental principles by means of which any legal order can be comprehended. As a theory, its sole purpose is to know its subject". 49

\section{ANALYTICAL JURISPRUDENCE}

The debates among legal philosophers about the correct account of the nature of law are part of the scientific process, which the investigation of general issues in epistemology and, of course, the discussion of the nature of conceptual analysis. Conceptual analysis is a method used in the explanation of law; it helps to learn more about the nature of the concept of law and deliver further understanding. The analysis and explanation of the concept guides us in the use of the concept and therefore in legal practice in terms of the creation and the application of norms.

An important claim of the analytical school is that legal philosophy can be distinguished from legal theory and other disciplines relevant to the study of legal phenomena such as sociology, history and moral studies of law. Kaufmann points out that no scientific philosophy can do without the analytical method, to which a synthesis must naturally follow. 50 In this sense, jurisprudence is not possible without analytical philosophy.

Analytical jurisprudence makes its appearance when the fundamental discussion on the scientific status of the study of law shifts from axiological to analytical questions. Contemporary legal theory shows formal-analytical orientation placing emphasis on legal logic, the philosophy of language

49 Idem.

50 Kaufmann, op. cit., note 5, p. 5. 
and the scientific theory of legal science. This formal analytical orientation of legal theory serves to intensify contact with other disciplines in the analysis of law (in general and particular aspects of law). ${ }^{51}$

As Troper mentions, in the 1950s, legal positivism regains an important audience with the development of analytical philosophy in Britain and the United States of America, and the term "general theory of law" becomes popular once more to designate the neutral description and analysis of law as a scientific method usually defined by its positivist orientation. ${ }^{52}$ Analytical legal theorists have focused their theories of law on the explanation of law within the context of the modern State. In fact, some even make the proper explanation of the nature of State law a criterion of adequacy for general theories of law. It represents a form of legal theory that is linked to theory of State to explain their mutual interrelation, both conceptually and functionally.

The concept of analytical jurisprudence refers to a theory that applies the philosophical method of linguistic analysis while still anchored to the legal culture that sustains a dialog with continental legal theory. ${ }^{53}$ According to the dominant understanding of analytical jurisprudence, its task is to offer a theory of law which identifies and explains the necessary (or sometimes qualified as 'essential') features of law. Some jurists focus on the precise use of theoretical language or on the vagueness of legal texts (legal hermeneutics) as a general theory of understanding.

Hart uses the philosophical method of linguistic analysis and distinguishes the law that is from the law as it should be, and elaborates on Bentham's and Austin's separability theses between law and moral. Hart sustains that positivist jurisprudence can be general and cognitive, and therefore

51 Neumann, Ulrich, "Rechtsphilosophie in Deutschland seit 1945", in Dreier, Faralli, Nersessiants (eds.), Law and Politics. Between Nature and History, Bologna, CLUEB, 1998, p. 272.

52 Troper, op. cit., note 3, pp. 32-33.

53 Barberis, op. cit., note 22, p. 89. 
neither interpretative nor normative, and that legal theory does not need to be evaluative. Thus, in setting jurisprudence in a descriptive discourse, he specifies however that "description may still be description, even when what is described is an evaluation". 54 The descriptive nature of analytical jurisprudence is assured in Kelsen's normativism since according to Paulson, it is characterized by the coupling of the separability thesis, which claims that the concept of law can be explained independently of morality, and the normativity thesis, which states that it can be explained independently of fact. ${ }^{55}$

In addressing the nature of legal philosophy in the Postscript to The Concept of Law, Hart states that his intention was to provide a general and descriptive theory of what law is. The aim was "to give an explanatory and clarifying account of law as a complex social and political institution with a rule-governed (and in this sense 'normative') aspect". ${ }^{56}$ In his work, Hart conceives legal philosophy as conceptual analysis and therefore a descriptive one. The purpose of conceptual analysis is to resolve boundary disputes about the concept of law by using the philosophical method of conceptual analysis.

Hart starts his explanation of law in The Concept of Law by asserting the relevance of the question about the nature of law and by explaining the reasons for its persistence. He does not consider it a defect of jurisprudence and says that even if one cannot offer a definition of law, its identification is in general possible by jurists and mentions how the answers given have contributed to the understanding of law. ${ }^{57}$ The problem is not the definition of law; it is not even the object of jurisprudence to offer a definition; its task is to delimit "the province of jurisprudence" by analyzing the struc-

54 Cfr. his Postscript, Hart, H. L. A., The Concept of Law, Oxford, Oxford University Press, 1994, p. 244.

55 Paulson, op. cit., note 18, pp. 227-244.

56 Hart, op. cit., note 24, p. 239.

57 Ibidem, pp. 1-2. 
ture of law, the role of coercion and the relationship between law and morality. Hart himself states that the object of this book was to "further the understanding of law, coercion and morality as different but related social phenomena". ${ }^{58} \mathrm{He}$ conceives it as an essay in analytical jurisprudence that has been acknowledged as a turning point in the way jurisprudence was understood and studied especially in the English-speaking countries.

\section{FINAL REMARKS}

After describing the general perception and evolution of jurisprudence and taking into account the different conceptions of this discipline in the two main western traditions, the amount of criticism made to analytical philosophy, as well as the rejection of descriptive analysis or explanation of law, may seem surprising. Descriptivism is part of the research program of jurisprudence. Hence, it is important to remember that the descriptive project of jurisprudence is to identify the necessary features of the concept of law. From the standpoint of conceptual difference or disagreement about law, one cannot infer that law has no necessary features that can be the object of scientific discussion. Epistemological questions regarding the purpose of general jurisprudence and the possibility of general jurisprudence in the terms of analytical jurisprudence have also been considered.

The reasons for the persistence in the analysis of the nature of law lie in numerous factors. Law is analyzed as an abstract concept, a human and sociological product of mankind, perceived through its manifestations and known by a reflective activity. It is a highly complex social phenomenon. This has in turn led some countries to adopt a multi-plane conception of legal theory that requires the acceptance of methodological pluralism due to the complexity

58 Ibidem, Preface, p. vi. 
of law since it considers that it comprises linguistic expressions, meanings, values, social behavior and psychological phenomena. This may not present methodological problems as long as it allows for the use of methods pertaining to the various scientific disciplines involved.

A central aim of the philosophy of law is to offer explanations of the general concepts of law and the concept of law itself. And as Bertrand Russell says, the value of philosophy "resides more in questions posed, in the relevance of their consideration and the persistence of the speculative interest than in the possibility of giving true answers". 59 Descriptivism has proven to contribute to a better understanding law. Analytical jurisprudence does not intend to discover necessary truths on law. Guibourg believes the analytical tradition is the best way to search for the answers required because it is the best way to elaborate the questions. ${ }^{60}$

Analytic legal philosophy is not generalized and despite the abundant literature, generalization does not seem to be treated as the object of the program of analytic jurisprudence. Conceptual analysis is a valid tool. The theoretical contributions of jurisprudence have proved of great practical value; there is a natural interaction between the theory and the practice in law.

The fact that legal philosophers have offered different theories to explain the same object of cognition does not preclude the relevance of their work. Kaufmann holds that only those who understand philosophy as the result of a work of hundreds of years and are willing to see the convergence in the divergence may overcome philosophical relativism. ${ }^{61}$ Controversial descriptions allow discussion, which is at the center of the progress of science.

To achieve the goal of this paper, few authorities were necessary: Kelsen and Hart drew the necessary lines to

59 Russell, op. cit., note 7, pp. 90-91.

60 Guibourg, op. cit., note 12, p. 297.

61 Kaufmann, op. cit., note 5, p. 4. 
reach a better understanding of jurisprudence. It seems fitting to conclude with Kelsen that "[a]s it is the task of natural science to describe its object - reality - in one system of natural laws, so it is the task of jurisprudence to comprehend all human law in one system of norms. This task, was unforeseen by Austin's jurisprudence, the pure theory of law, imperfect and inaccurate though it may be in detail, has gone a measurable distance toward its accomplishment". ${ }^{62}$ Theorizing about law as was done before John Austin, understanding legal philosophy as part of normative political philosophy, is not an alternative to descriptivism. Analytical jurisprudence cannot be substituted for political theories since they are different from, though not alternative models to, descriptive legal theories.

62 Kelsen, op. cit., note 25, p. 70. 
DR (C) 2012, Universidad Nacional Autónoma de México,

Instituto de Investigaciones Jurídicas 